\title{
Prevention of Internet Financial Risks in the Era of Digital Economy
}

\author{
Yan Wang* \\ Endicott College, Woosong University, Daejeon 300-718, South Korea \\ *Corresponding author: Yan Wang, awangyan@gmail.com
}

\begin{abstract}
As a pillar in the development of China's economy, the financial industry plays a key role in the production and life of residents. Along with the widespread application of the internet, internet finance has gradually emerged as required by the times, and in the achievement of the collection and extraction of big data, related analysis and exploration technologies have been emphasized more. However, in the context of big data technology, there are still risks of unsound laws, inadequate business publicity, user information security, and capital liquidity in internet finance. Under this digital economy era, this article attempts to discuss these risks, which need to be prevented from establishing a good internet financial system, strengthening interindustry exchanges and cooperation, building a unified internet financial information supervision platform, as well as optimizing the internet financial credit reporting system, so as to promote a healthy and sound development of the whole financial industry.
\end{abstract}

Keywords: Big data; Internet finance; Third-party payment; Risk; Prevention

Publication date: October 2021; Online publication: October 29, 2021

\section{Background}

\subsection{Literature review}

At present, there are many research on internet financial risks. A relatively rich research theory has been formed, laying a good foundation for the research of this article. Chen Jiayan believes that in the context of big data, internet financial risks have become an important issue of concern to all sectors of the society and pointed out that the emerging stage of China's internet financial risks basically involves credit risk, market risk, and technical risk. Moreover, with the increase in internet financial risks, it is increasingly difficult for regulatory authorities to prevent risks. Relevant departments should use the big data credit investigation legal system to form a specific protection system to promote a sound and healthy development of the entire internet financial environment ${ }^{[1]}$. With the rapid development of mobile communication technology, $\mathrm{Li}$ Xuehong found that the big data technology in China is gradually improving and deepening into the financial field, prompting the rapid development of related fields. However, in the context of big data, the financial sector needs to continuously pay attention to internet financial risks and take specific precautions to ensure the continuous development of the entire internet financial industry ${ }^{[2]}$. Li Gang and Li Xiangfei explored the impact of the internet on the traditional financial industry under the context of the rapid development of big data, blockchain, and cloud computing technologies. The study found that in this environment, the internet has significantly increased the operational risks of the traditional financial industry. Therefore, the scholar proposed to improve the organizational framework of financial institutions, establish internet financial risk prevention and early warning, as well as optimize financial business processes to better prevent those risks ${ }^{[3]}$. Chen Si pointed out that the prevention of financial risks is the key to the operation of internet finance, which is directly related to a healthy operation of the entire financial 
system. In this context, the scholar deeply explored the problems of the financial industry in preventing internet financial risks in the past and proposed targeted control suggestions to continuously improve the risk control level as well as provide a decision-making basis for related industries ${ }^{[4]}$. On the basis of the in-depth exploration of the current development of internet finance, Liu Jun found that big data technology plays a significant role in the operation of the internet financial system. However, big data technology also has a huge impact on internet finance, resulting in many internet financial risks, which need to be resolved quickly ${ }^{[5]}$. Zheng Siying pointed out that after the reform and opening-up, the financial industry in China has gradually entered a stage of rapid development. With the increasing changes of modern science and technology, some new technologies, such as big data and internet, have greatly impacted the financial industry. This leads to the gradual inability of the internet financial industry to meet the financial needs of related fields, which is not conducive to the rapid development of the whole industry. Therefore, in the context of the rapid development of big data, the financial industry needs to focus on internet financial risks and implement relevant risk prevention measures as soon as possible ${ }^{[6]}$.

\subsection{Purpose of the study}

With the rapid development of modern science and technology, emerging technologies such as big data, internet of things, and the internet have developed rapidly and achieved remarkable results ${ }^{[7]}$. In this process, emerging science and technology have greatly impacted the financial industry, especially on the financial development model. Particularly in the field of internet finance, the rapid development of big data technology does not only accelerate the development process of internet finance, but also raise challenges to its development. As an emerging industry in recent years, internet finance has made up for the disadvantages of the traditional financial industry in view of its wide coverage, fast transaction, and simple operation. This makes the internet financial access threshold significantly lower. In the context of the rapid development of big data technology, the rapid development of internet finance is accompanied by potential risks and challenges, which may bring many adverse effects to the financial industry. Therefore, on the basis of delineating the basic concepts of internet finance, this article deeply explores the risks of internet finance and put forward specific prevention suggestions to provide theoretical guidance for the development of related industries.

\section{Connotation of internet finance}

Internet finance refers to the high integration of finance, internet, and internet of things, in addition to the integration of capital, payment, and relevant information with the help of big data technology, so as to promote the continuous transition of the financial industry in the direction of informatization and realize the informatization development of capital, payment, as well as investment and financing ${ }^{[8]}$. In specific application, internet finance can break through time and space constraints, help related parties save transaction costs, and promote the fast reading as well as efficient use of money. From the perspective of the types of internet finance, there are various modes of development (Table 1). According to Table 1, internet finance includes P2P, digital currency, internet financial portal, big data finance, and third-party payment. It can be seen that the development of internet finance is diversified with various models. Each model has its own characteristics, and there are great differences among different models in the fields of application. For example, P2P mainly refers to a peer-to-peer credit model, which is an abbreviation of online loans, including commercial online loans and individual online loans ${ }^{[9]}$. Its characteristic is as follows: with the help of an intermediary platform, it helps borrowers and other lenders to share the borrowing quota, thereby diversifying the credit risk. P2P is also a typical online lending model. Generally, individuals use a third-party internet financial platform to match the borrowers of funds to meet the funding 
needs of dual entities.

Table 1. Characteristics of internet financial models and their specific applications

\begin{tabular}{|c|c|c|c|}
\hline Category & Concept & Feature & Scope of application \\
\hline $\mathrm{P} 2 \mathrm{P}$ & $\begin{array}{l}\text { Refers to a peer-to-peer credit } \\
\text { model, which is an abbreviation } \\
\text { of online loans, including } \\
\text { commercial online loans and } \\
\text { individual online loans. }\end{array}$ & $\begin{array}{l}\text { With the help of an intermediary } \\
\text { platform, it helps borrowers and } \\
\text { other lenders to share the loan } \\
\text { quota, thereby diversifying the } \\
\text { credit risks. }\end{array}$ & $\begin{array}{l}\text { A typical network loan model that } \\
\text { is generally through third-party } \\
\text { internet financial platforms, where } \\
\text { individuals match both sides of the } \\
\text { loan to meet the needs of the two } \\
\text { main funds. }\end{array}$ \\
\hline $\begin{array}{l}\text { Digital } \\
\text { currency }\end{array}$ & $\begin{array}{l}\text { The main form to replace } \\
\text { electronic currency. }\end{array}$ & $\begin{array}{l}\text { With the help of blockchain } \\
\text { technology, the characteristics of } \\
\text { decentralization, low cost, and } \\
\text { speed of capital transactions are } \\
\text { realized, and the information } \\
\text { security of the transaction subject } \\
\text { can be highly guaranteed during } \\
\text { the transaction process. }\end{array}$ & $\begin{array}{l}\text { It has a wide range of application } \\
\text { and is not subjected to any } \\
\text { restrictions. It can realize a two- } \\
\text { way circulation between virtual } \\
\text { currency and real currency. }\end{array}$ \\
\hline $\begin{array}{l}\text { Internet } \\
\text { financial } \\
\text { portal }\end{array}$ & $\begin{array}{l}\text { The marketing of financial } \\
\text { products with the help of internet } \\
\text { finance. }\end{array}$ & $\begin{array}{l}\text { Information search is safe and fast, } \\
\text { matches in a fast way, pays great } \\
\text { attention to user experience, and } \\
\text { greatly highlights the value of } \\
\text { related channels. }\end{array}$ & $\begin{array}{l}\text { Vertical search platforms, third- } \\
\text { party consulting platforms, and } \\
\text { financial supermarket platforms. }\end{array}$ \\
\hline $\begin{array}{l}\text { Big data } \\
\text { finance }\end{array}$ & $\begin{array}{l}\text { With the help of big data } \\
\text { technology, it constantly } \\
\text { changes the traditional financial } \\
\text { development theory, mode, and } \\
\text { technology as well as forms an } \\
\text { internet financial mode that } \\
\text { matches the global development. }\end{array}$ & $\begin{array}{l}\text { Based on big data technology, it } \\
\text { establishes a supply chain finance } \\
\text { that forms a modern industry. }\end{array}$ & $\begin{array}{l}\text { Banking, securities investment, } \\
\text { insurance, and other core areas of } \\
\text { financial industry. }\end{array}$ \\
\hline $\begin{array}{l}\text { Third-party } \\
\text { payment }\end{array}$ & $\begin{array}{l}\text { An online payment mode in } \\
\text { which independent institutions } \\
\text { with financial strength use banks } \\
\text { or networked institutions to } \\
\text { complete dual-subject capital } \\
\text { transactions. }\end{array}$ & $\begin{array}{l}\text { Payment is convenient, and } \\
\text { various bank cards can be merged } \\
\text { into a virtual interface to realize } \\
\text { the convenience of fund payment. }\end{array}$ & $\begin{array}{l}\text { Life payment, online shopping, } \\
\text { and letter of credit settlement. }\end{array}$ \\
\hline Crowdfunding & $\begin{array}{l}\text { Generally, refers to fund-raising } \\
\text { activities initiated by individuals } \\
\text { or organizations with the help of } \\
\text { crowdfunding platform. }\end{array}$ & $\begin{array}{l}\text { Mainly introduces the basic } \\
\text { situation of the project to the } \\
\text { public through its own platform, } \\
\text { and then urges the masses to raise } \\
\text { funds. }\end{array}$ & $\begin{array}{l}\text { Private fundraising, art creation, } \\
\text { free software research and } \\
\text { development (R\&D), platform } \\
\text { fund lending, and other matching } \\
\text { fields. }\end{array}$ \\
\hline
\end{tabular}




\section{Analysis of internet financial risks in the context of big data}

\subsection{Unsound laws}

Under the big data environment, there is a mismatch between the development of internet finance and related laws, which hinders the effective development of the financial industry. It is embodied in two aspects. On the one hand, there is a lack of laws and regulations for the development of internet finance in a big data environment. At present, the policy departments in China have not issued any relevant laws or regulations for the development of internet finance under the big data environment, resulting in the lack of specific regulatory rules and legal constraints for the development of related financial industries as well as the difficulty in achieving efficient operation ${ }^{[10]}$. On the other hand, there is a lack of specific operating rules for internet finance. Although the People's Bank of China has issued several rules and regulations to guide the development of internet finance, there are no specific laws or policies for the development of relevant financial institutions, resulting in the lack of targeted document support for corresponding business processes and the difficulty in achieving achieve standardized operations.

\subsection{Inadequate business publicity}

As a huge business system, internet finance is supported by different business processes in the specific operation process. In the actual application of internet finance in related fields, although specific business processes have been implemented, they have not effectively promoted the related business processes, resulting in the lack of specific practical cases for application personnel, which is not conducive to accelerating the efficiency of related business applications ${ }^{[11]}$. For example, in the actual application process of a third-party payment service, it can be subdivided into two major ports: individual users and enterprise users. The specific business processes of the two major ports are somewhat different and require different guidance (Figure 1). However, relevant financial companies have not publicized specific business processes to users or companies for third-party payment services, resulting in greater limitations in the business circulation operation. Especially for user groups, financial companies have not conducted business process application training for the majority of users. Majority of the elderly groups still rely on traditional financial management methods and have not experienced the convenience of internet finance. This is not conducive to the large-scale publicity of related businesses.

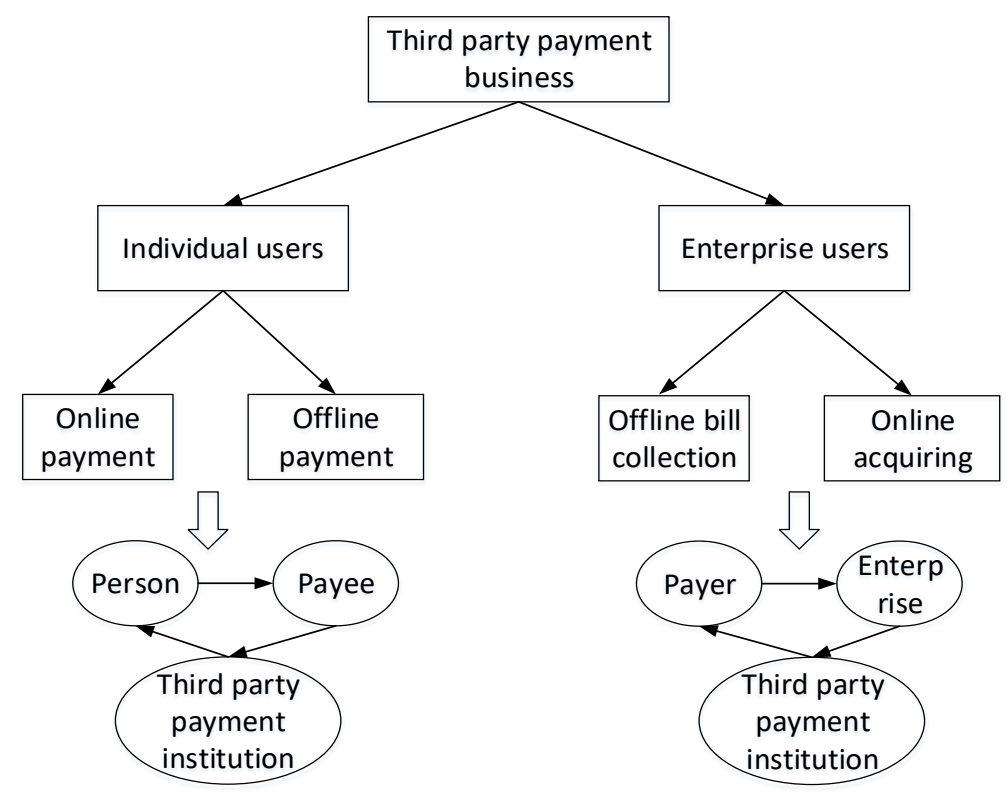

Figure 1. Third-party payment business process 


\subsection{User information security}

Internet finance involves a lot of information and data, so it is necessary to effectively maintain the privacy and security of relevant application subjects. However, in the actual application process, the rapid spread of information and the borderless characteristic of the big data environment itself ensue a difficulty in achieving seamless connection between the real world and the internet environment in a short time. In such an environment, user personal information, such as behavioral location, operation traces, health and financial information, etc., can be exploited easily by other users. Moreover, in the context of the era of big data, internet finance has not set up targeted systems and dedicated websites for user privacy protection, resulting in a large amount of user information being detached from related systems and the difficulty in efficient application to specific subjects. In addition, under the influence of big data technology, user behavior trajectories and personal information have exceeded the boundaries and scope of traditional identity recognition, which can easily create conditions for online fraud and increase the risk of cybercrime.

\subsection{Liquidity}

Under the big data environment, the internet financial payment system is relatively simple, and it generally needs to be realized through capital turnover. Funds are transferred to the internet financial payment platform with the help of the banking platform, and then used in various consumer fields. In this process, the user needs to be confirmed by the dealer in the process of using the funds, and then the specific allocation can be realized. The risk of this payment process is that there is a large time difference between various funds payment, which brings greater risks to the smooth development of internet finance in addition to the risk funds embezzlement among customers. Some internet financial institutions are using emerging methods to establish a capital reserve system to reduce the negative impact of the time difference. However, the liquidity risk of funds has always existed and is difficult to eradicate. At the same time, although the development of internet finance has, to a large extent, revitalized idle funds in various fields, many trading modes have been derived, such as virtual currencies. The long-term application of this transaction model has caused many uncertain risks in the overall economic development of the country and has also led to the existence of capital flow risks in the financial economic system, which is not conducive to the smooth operation of the entire financial industry.

\section{Prevention of internet financial risks in the context of big data}

\subsection{Establishing a sound internet financial system}

The financial system has always been the key to preventing and controlling financial risks, and it is also the fundamental basis for the development of the financial industry. Therefore, in order to ensure a healthy and sound development of internet finance, it is necessary to establish a good institutional system. First, improve the internet financial business system. On the basis of the original internet financial business system, financial institutions should combine the current development trend of emerging technologies to continuously improve the operation process and specific business indicators of related business systems to better connect with users. Only by improving and innovating the internet financial business system, the overall development of the financial industry can be stimulated, the processing efficiency of related businesses in the industry can be improved, and its own profitability can be enhanced. Secondly, rationally adjust the structure of internet financial business. State-owned financial enterprises should closely follow the pace of big data technology development, actively adjust the overall internet financial structure, enhance corporate innovation capabilities, and promote corporate operational capabilities. In addition, financial institutions should conduct extensive research in the market to understand the basic needs of customers, continuously improve the internet financial system, as well as launch a service system to better match user 
needs and improve their own business turnover efficiency. Finally, improve the internet financial management system. Industry institutions should take the overall development of financial enterprises as the main breakthrough point, introduce a targeted financial industry management system, and continuously improve their business management. On this basis, a standardized management method is used to restrict the behavior of financial enterprises, so as to strengthen the ability of enterprises' risk prevention and maximize the improvement of their risk management system.

\subsection{Strengthening interindustry exchanges and cooperation}

In the big data environment, the barriers in financial industries have gradually been blurred, and highfrequency cross-industry exchanges have been achieved. The exchanges among different industries can fully reflect the actual situation of relevant business operations, facilitate the formation of specific solutions, as well as help prevent and respond to risks in the same industry. Therefore, in response to internet financial risks, the financial industry should encourage a large number of interindustry exchanges to form an internet financial risk prevention mechanism. On the one hand, the financial industry should start with big data technology, strengthen exchanges and cooperation with the e-commerce industry, propose targeted solutions based on the characteristics and risks of the current internet financial development, and then establish more complete solutions and strengthen self-risk resolution capabilities. On the other hand, the financial industry should further emphasize on the supervision and coordination role of industry institutions and use big data technology to strengthen exchanges as well as cooperation with similar industries from different countries and regions. Through massive data collection and analysis, the financial industry should strengthen exchanges and cooperation with enterprises in the industry, establish an internet financial risk management system, strengthen the ability to identify and control related risks, as well as maximize the avoidance of internet financial risks.

\subsection{Building a unified internet financial information supervision platform}

Beginning in 2009, the People's Bank of China began to build provincial-level data centers on a large scale to standardize the application and circulation of massive data. After that, the Public Security Department of Liaoning Province brought together many banks and held a joint supervision and innovation meeting between public security organs and banks to achieve effective supervision of regional internal data. Therefore, in response to internet financial risks, a unified internet financial information supervision platform should be established. First of all, financial institutions should use big data technology to achieve strategic cooperation with relevant technology companies, so as to coordinate relevant internet financial services and form a targeted information supervision platform. Second, on the established internet financial information supervision platform, financial institutions should then establish contacts with companies in the same industry, unify information on internet financial development, as well as complete information classification and sorting. Thereafter, the release of relevant information should be completed in a unified manner to realize the rationalized application of relevant information. Finally, for the internet financial information supervision platform, financial companies should set up special management personnel and permissions for the management of the platform's internal information collation, release, and application, so as to effectively ensure the security of internet financial information. To sum up, through the establishment of an internet financial information supervision platform, relevant information can be collected, sorted, classified, and then applied uniformly, thus maintaining the privacy and security of users and effectively improving the application security of relevant platforms. 


\subsection{Optimizing the internet financial credit investigation system}

At present, the internet financial credit reference system is still flawed as it is unable to regulate the internet financial business, and it brings greater application risk to users. Therefore, in order to prevent internet financial risks, it is particularly necessary for relevant institutions to optimize and improve the internet financial credit system. On the one hand, financial institutions should cooperate with relevant regulatory agencies to set up a targeted credit reference system for internet finance in order to strengthen the information supervision mechanism of relevant companies and prohibit relevant personnel from obtaining user information by illegal means. Moreover, the credit system should include the punishment mechanism for illegal information application, so as to create a good financial environment for users in the application of internet finance. On the other hand, the relevant management departments should rectify some nonstandard and dishonest behaviors to increase the cost of internet financial dishonesty. Once the cost of internet financial dishonesty increases, there would be a lot of negative effects on relevant personnel and even serious consequences to some users. In this way, a good internet financial application environment can be formed, which is conducive to the better identification and prevention of internet financial risks among users.

\section{Disclosure statement}

The author declares that there is no conflict of interest.

\section{References}

[1] Chen JY, 2020, Research on Internet Financial Risks and Preventive Measures in the Context of Big Data. Mall Modernization, 49(20): 145-147.

[2] Li X, 2020, Internet Financial Risks and Preventive Responses in the Context of Big Data. Friends of Humanities, 13(1): 74.

[3] Li G, Li X, 2019, Research on the Prevention of Internet Financial Risks in the Context of Big Data. Red Son, 19(24): 130-131.

[4] Chen S, 2018, Risk and Prevention of Internet Finance in the Context of Big Data. Enterprise Technology and Development, 34(8): 264-265.

[5] Liu J, 2018, Research on Internet Financial Risks and Countermeasures in the Context of Big Data. Enterprise Science and Technology and Development, 34(3): 8-9.

[6] Zheng SY, 2020, Internet Financial Risks and Prevention and Response in the Context of Big Data. Market Research, 68(1): 42-43.

[7] Xie Y, 2018, Exploration of Internet Financial Risk Regulation in the Era of Big Data. Times Finance, 39(29): 61-62.

[8] Zhang Siwei, 2017, Research on the Prevention and Control Methods of Internet Finance Risks Based on the Background of Big Data Era. Contemporary Tourism (Golf Travel), 5(60): 52.

[9] Fan Y, 2016, Exploring the Development Mode of Internet Financial Innovation under Big Data. China Market, 23(24): 115-116.

[10] Li Z, 2020, Exploration of Internet Financial Risk Prevention and Control Measures in the Era Of Big Data. Perspective View, 4(9): 1.

[11] Hu RH, 2020, Exploration of Preventive and Control Measures for Internet Finance Risks in the Era of Big Data. Mall Modernization, 43(4): 118-119. 